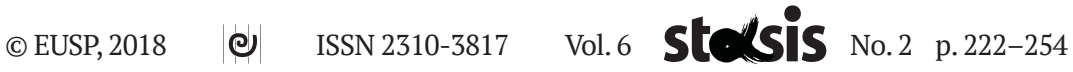

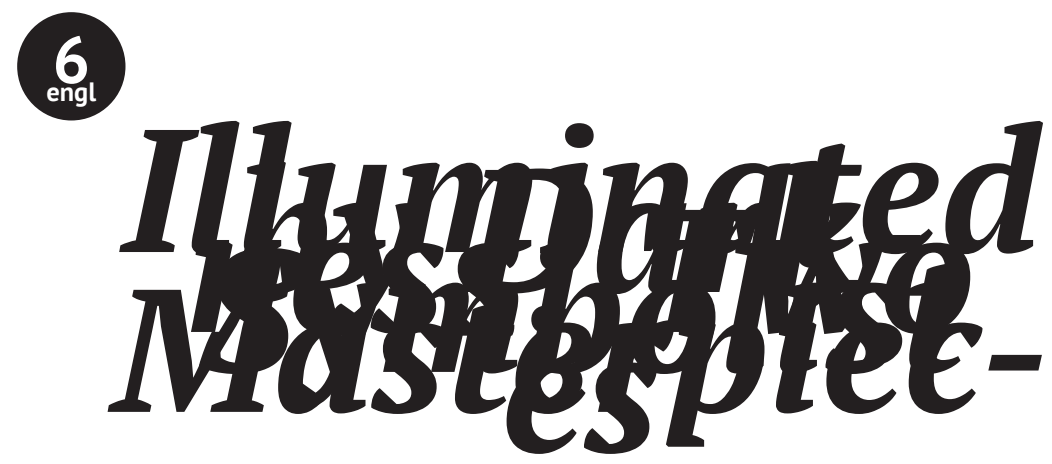

Artemy Magun

Professor of Democratic Theory,

European University at St. Petersburg,

Department of Sociology and Philosophy

6/1A Gagarinskaya Street, St. Petersburg, Russian Federation 191187

E-mail:amagun@eu.spb.ru

\title{
Illuminated by Darkness: Two Symbolist Masterpieces
}

\begin{abstract}
The article is dedicated to the problem of negativity in modernist art. It ties together the substantive gloom of a modernist artwork with the catastrophes that happen at the level of its form. In this sense, there is a difference among the shock aesthetic of mass culture, the abstraction of avant-garde, and the ideological and figurative construction that is provided by a symbolist artwork. The article offers an apology of symbolism, primarily in plastic arts, and demonstrates its incessant influence.
\end{abstract}

Keywords

symbolism, negativity, Lars von Trier, Jacek Malcziewski, aesthetics 


\section{Introduction}

This article is a continuation of my earlier meditation on the nature of the dark and melancholic tone in culture, particularly in the culture of the present era. I am writing not as an art historian (which I am not), but as a philosopher trying to understand the strange, disquieting, yet deeply fascinating phenomenon of melancholia. Both contemporary high and mass culture are marked by it (detective and Hollywood science fiction movies are some of the obvious examples of melancholia in popular art). Of course, a sadomasochistic poetics of suffering has always had its place in art as well as religion. And yet, there is something particular to contemporary moody art - it offers compassion but not catharsis (even when catharsis is present, it is not genuine - as with "happy endings" in Hollywood), death but not redemption (if there is some redemption, it does not absolve the suffering, as in Lars von Trier's Breaking the Waves), horror but not domestication. Moreover, we can watch these processes in their dynamic unfolding. American cinema has been fascinated with the uncompromising representation of violence since the late 1960s. In the past two decades, detective prose has taken yet another turn toward cruelty and naturalism. The tragicomic world of Latin American prose of the '60s (Julio Cortazar and Gabrial Garcia Marques) was supplanted by the dark heroes of the '90s (J.M. Coetzee, W.G. Sebald, Michel Houellebecq). Even James Bond had grown melancholic by the mid-2000s. All of this was taking place in the 1990s and early 2000s - a time of a general liberal triumphalism that would only gradually devolve into a nightmare before our eyes.

This shift toward melancholia was particularly noticeable to the Soviet audience that was accustomed to the classicist poetics of so-called Socialist Realism - a poetics to which many avant-garde artists would respond. Such gloomy Soviet authors as Lyudmila Petrushevskaia and Vladimir Sorokin managed to shock and impress their readers precisely because their works sharply contrasted with the prevalent system of collectivist catharsis and humor that used to be the main acceptable mode for portraying horror and suffering. The turn toward grimy naturalism that Russian art took in the 1990s has it closer to the West, even though there naturalism would come into fashion only a little later.

Does this have anything to do with critical realism that could expose capitalism's fissures and there serve a progressive function? Partly. However, both contemporary mass and arthouse cinema tend to show not the oppression of the poor, but the existential crisis of a depressive and lonely bourgeois subject. It turns out that art had grasped the nature of capitalism's crisis long before it arrived. It became a confirmation not of a socialist, but of a conservative critique of the West - showing it 
as alienated, spiritually bankrupt, and cut-off from its origins - without, however, offering any real alternative.

Negativity in art is not exclusive to our times. It is typical to all art in general (as a self-overcoming of religion), especially in its sublime and tragic forms. Still, we have known periods of classicism and academism, during which art abided by a set of rules and adhered to "realistic" mimesis. During these periods, negativity was subjugated by idealization. Soviet art from the 1930s to the 1980s went through one such period. And it is in contrast with such art that the contemporary Russian aesthetic of negativity stands out with particular intensity. Turn-of-the-century European modernism, on the other hand, was from the very beginning characterized by rebellion against all canons and by a deliberate attack on form and mimetic resemblance. It was colored by shock, horror, and sorrow. This negativity was noted and analyzed - albeit from two different critical positions - by Theodore Adorno in West Germany and Mikhail Lifshitz in the USSR. Adorno (1997) regarded modernist negativity as an objective expression of the alienated subject, as a remainder of a non-identical experience, while Lifshitz saw it as a nihilistic "integrated rebellion" (2009: 40-57). Both positions can be reconciled if we consider negation in recent art not as nihilistic destruction and sentimental shock, but as a correlation of reality with its ideal, in the process of which the terms could at times switch their meanings in an unfree society: time and time again, Ideal appears in its demonic form and incarnations of angelic light bring suffering on the exhausted flesh. Still, it is precisely from negativity that beauty springs (and not the sublime as in the mainstream of avant-garde art). This art, that exists in-between classicism and nihilism, has been historically referred to as symbolism. It is this art that I turn to below, in more detail.

The notion of "negativity" was first introduced by Hegel to be later picked up by twentieth-century philosophers, specifically by members of the Frankfurt School. Certainly, this term is familiar to my reader, yet it is worth emphasizing that behind it stands an entire philosophy, that is, thinking about the totality and materiality of the negative effort that might otherwise appear as a trivial logical operation. The fact that the subject negates the immediate data of experience to distinguish an object is due to the presence of a strange supernatural force. This force does not stop at differentiating objects, but strives further--to the limit of destruction, homicide, and evil that it later abandons, thanks only to the reflexive gesture of the "negation of the negation." In other words, in negativity logical and ethical negations are intrinsically linked.

Already in 1805-06, in his Jena Lectures Hegel writes that the subject ("Spirit") "complements this [being-in-itself] with the for-itself, with negativity [...] It takes its first self as an object, i.e., the image, Being as mine, as negated" (Hegel 1983: 86). Particular being is negated, it be- 


\section{Illuminated by Darkness: Two Symbolist Masterpieces}

comes an image and only in this capacity enters the into the negative interior space of a person: "It is stored in the Spirit's treasury, in its Night [...]The human being is this Night, this empty nothing [...] in phantasmagoric representations it is night everywhere: here a bloody head suddenly shoots up and there another white shape, only to disappear as suddenly. We see this Night when we look a human being in the eye, looking into a Night which turns terrifying. [For from his eyes] the night of the world hangs out toward us" (Hegel 1983: 86-87).

This fragment simultaneously contains logic, ethical emotion of horror, and aesthetic theory of image based on a fashionable-at-the-time Romantic model (especially that of Novalis), which, however, already anticipates the Neo-Romantic symbolist aesthetic. Night in Hegel's passage is an image that is also a symbol. I will discuss this further, once I address Hegel's theory of symbolic art.

It is not accidental (see Denisoff 2007) that the next wave of aestheticism in European culture (third after Renaissance and Romanticism) was characterized by decay and decadence and ended up claiming the latter description as its title. Exuberant artistic imagination - stimulated by the electric new energy of life, by the loosening of official control over practices that were earlier considered sinful, improper, or impractical, and by the economy of consumption and advertisement - began to sharply contradict the rational spirit of technological progress. All this found reflection in the "negative" self-consciousness of the early proto-modernism, which experienced itself as "decadence." "Impressionism," "symbolism," and, of course, "decadence" - these names were first introduced pejoratively by these movement's critics. It is symptomatic and interesting that they were all eventually accepted (not without some irony) by the artists themselves.

Although both "symbolism" and "decadence" were used interchangeably in reference to the same artists and writers, the name "symbolism" appeared to have more positive connotations. And yet, as I will demonstrate further, the melancholic tone associated with the decadents was not entirely overcome in symbolism, especially in symbolist painting, where it was literally embodied in the darkened and contrast-filled coloration. Symbol itself was primarily conceptualized negatively. For instance, Stéphane Mallarmé drew on the Hegelian theory of a symbol as standing in a negative relation to the sign. In Russia, Nikolai Minsky set forth a highly influential negative theory of the symbol. Combining Neo-Kantianism and Neoplatonism, Minsky proposed a concept of a "meon" ("the non-existent") as a transcendental form, to which one could ascend only through negation. "All of life, all of the world is enveloped by a mysterious atmosphere of meons. [...] Art in itself does not guide us to meons, but it creates symbols of different stages of development" and therefore "should lead to its own negation” (Minsky 1897: 216). This negation, however, 
is only relative - it exists only for us. Within themselves these ideasmeons are quite positive. The distinction between symbolist self-consciousness and that of the decadents is contained in this distinction. Whether or not it held in practice remains an open question.

The rise of the avant-garde at the beginning of the twentieth century has undoubtedly entailed, among other things, a break with the "decadent" themes of symbolism: its pessimism, its auratism, and its commitment to "story." This break, however, was not a decisive one. Kazimir Malevich, Velimir Khlebnikov, Wassily Kandinsky, Paul Klee, Daniil Kharms, and Piet Mondrian - all paid their tribute to mysticism. In that regard, they were not that different from the turn-of-the-century symbolists (Fa$\cos 2015)$.

Symbolism is closely related to the art of modernism. Symbolists were the first to make a step toward anti-naturalism, partial abstraction, fantastic plots, and expressivity. For the purposes of this essay, I am inclined to separate the notions of modernism and the avant-garde, counter to Clement Greenberg and in agreement with Peter Bürger and Johan Schulte-Lasse. ${ }^{1}$ Symbolism could be seen already as modernism but not yet the avant-garde.

It is possible to make several interesting connections between the late nineteenth century and the present era. As I will show further, a series of contemporary cultural phenomena, for example the cinema of Lars von Trier and popular sci-fi, make direct references to the symbolist epoch. Birgit Beumers (2013) draws a parallel between fin-de-siècle Russia and the postcommunist Russia of the 1990s. She holds that both periods were marked by their overt nihilism and confusion, which gave rise to decadent culture. A close consideration of these two epochs and cultures, however, reveals more differences than similarities between them.

Today we can confidently claim that the period of the late nineteenth and early twentieth centuries was exceptionally meaningful for European art. A radically new understanding of art emerged and with it new schools, styles, genres, and countless masterpieces that set the course for the rest of twentieth-century culture. It is important that the neither the chronol-

1 Historically, these terms have been defined in many different ways. In the US, beginning with Greenberg’s “Avant-Garde and Kitsch” essay, avant-garde and modernism tended to be conflated. German Art History, on the contrary, tends to separate them: avant-garde is understood as an art of social protest (and rightfully so), something that most modernist art of formal experimentation has nothing to do with. (Bürger's Theory of the Avant-Garde and Schulte-Lasse's introduction to it are particularly good examples of this line of thought.) I suggest that we distinguish between modernism and the avant-garde: The former, as a tendency to absorb the world into a work of art, while the latter as its opposite - a rejection of the autonomy of art and desire to dissolve art in life. 
ogy of the fin de siècle, nor that of modernism was linear. In the 1910s and 1920s a shift, or, rather, a leap takes place from decadence and symbolism to the more daring revolutionary-minded avant-garde (which includes cubism and futurism). We also have a parallel development of German expressionism that flows smoothly out of symbolism and becomes a continuation of its program; it takes on symbolism's decadent mood as well, adding to it an element of shock. We also see the development of French surrealism - a style that is considerably more hedonistic and optimistic in spirit, but that is closely tied to symbolism by their shared aesthetic of the fantastical and the neoclassical. Russia in the 1920s witnessed not only a development of revolutionary constructivism and suprematism, but also a blossoming of high modernism that inherited symbolism's main traits: figurativity, idealism, and virtuosity (we can name the literary writing of Osip Mandelshtam and Andrei Platonov as examples of such high modernist works).

Late nineteenth-century modernism was characterized by aestheticism and a religious attitude to art. Modernism is saturated with eschatological mood and this mood inspires it to destroy artistic form. Orientation toward deformation allows not only to set a melancholic tone, but also to create an effect of a trance, to hypnotize the viewer into feeling herself transported to another reality. The line between nineteenth and twentieth centuries demarcated a break between two different branching cultural paradigms. Symbolism, which emerged as a dominant genre in this transitional period, combines formal experimentation with figurative naturalism, or even classicism. Its contemporaries, primarily in Britain, tended to view symbolism as a protest movement, since it insisted on the freedom of imagination and the deformation of "realistic" proportions (Gibson 1995: 8). And yet, its intention was the opposite of that of impressionism, which from the very beginning placed its bets on non-ideological aestheticism. Rejection of figurativeness and playing with forms of expression in symbolism were meant to accentuate the viewer's sensuality and to encourage her to re-evaluate habitual forms. Contemporary theories of modernism - for instance, that of Jacques Rancière - begin precisely from this sensualist model of art (Rancière 2004). However, symbolism is rather a modernist movement that follows a different trajectory. A disruption of form here is conceptualized as a collision with an object that remains elusive and foreclosed in its intensity, as a chance encounter in a "thoughtfully ordered disorder" with an object that embodies the Ideal (Moréas 1886:1). By rejecting the canon, symbolism becomes conscious of the incompleteness of all negation and frankly presents the audience with a shocking event (for instance, with a story of a murder or disgrace), as well as with a figure of a person astounded by this event (think of Edvard Munch's screaming hero). Andrey Bely's novel Petersburg (1978 [1913-14]) is quite a characteristic work in this regard. 
It is constructed around the expectation of a bomb's explosion and it itself blows up the usual literary form, but in such a way that, like a half-destroyed city, this form still remains habitable. One could wander around it as one would around a labyrinth. In a sense, Bely seems to be a more honest writer than James Joyce, whose writing has a similar form. In Joyce's novel (1986) (unlike in the Odyssey), there is no other catastrophe besides the catastrophe of language, and even it may go unnoticed, obscured by the impressionistic ideology of the stream of consciousness "as it is."

When Walter Benjamin, in his well-known apocalyptic ode to the avant-garde, rallies against aura as "unique apparition of a distance, however near it may be" (2006a: 272), he is opposing twentiethcentury avant-garde movements that developed out of impressionism (cubism, futurism, and constructivism) to the more objectively minded symbolism, which, however, is also more passéist. At the same time, Benjamin's own late philosophy of history ("to snatch humanity at the last moment from the catastrophe looming at every turn" [2006b: 188]), and his analysis of the art nouveau style in his Arcades Project, on the contrary, gravitates toward the auratic and symbolist sense of time.

Politically speaking, symbolism (just as Romanticism one hundred years earlier) was a deeply ambivalent phenomenon. In France it was seen as a rather conservative, archaistic and academic style. In Great Britain, on the other hand, against the backdrop of rational and pragmatic culture, symbolism looked radical and oppositional. In early twentieth-century Russia, most of the symbolist authors sympathized with the revolution and adhered to leftist, anarchist, and (less frequently) socialist positions (which often coexisted with religiosity).

Russian symbolism was in direct connection with revolution, in particular with the revolution of 1917. Symbolist writers such as Maxim Gorky, Alexander Blok, Valery Bryusov, and Bely, their "heirs" such as Boris Pilniak and Platonov, and even Alexander Bogdanov of the Red Star; painters such as Kuzma Petrov-Vodkin, early Pavel Filonov, and Marc Chagall - all responded to revolution with enthusiasm. They hastened to glorify its wild and mystical energy: tempests, snow-storms, society gods and goddesses, Neo-Renaissance geniuses, etc. At the same time, Bolsheviks (and history itself) initially sided with more rational and futuristic art that is more correct to associate with the avant-garde (Aleksei Gastev, Vladimir Mayakovsky, Vladimir Tatlin, Malevich, and others) than with modernism or symbolism. Symbolist perception of an event tends to be apocalyptic. It is not accidental that Bely in his Petersburg inscribes an act of anarchist terror into apocalyptic, rather than optimistic revolutionary narrative. The novel is all intoxication with the raging revolutionary elements, but the overall feeling that it leaves is that of being "on the somber abyss on the edge." One can be critical of such a romantic and archaic view of the Revolution that was a progressive and secularizing 
phenomenon. The fact that Socialist Realism and Soviet hagiography would later come to borrow symbolist themes does not help symbolism's case. And yet, authentic symbolism is not about sugarcoated nostalgia. It is a dissonant consonance of an event. Symbolism played its role in that it forced the most forward-looking of Russian culture to check itself against the standard of revolutionary heroic negativity (think, for instance, of the melancholic tone of the film Chapaev, of such novels as The White Guard, The Master and Margarita, Doctor Zhivago, which were White in spirit, but written and read in the USSR, and the philosophical works of Mikhail Bakhtin, Evald Ilyenkov, and Boris Porshnev).

In what follows, I will give the brief philosophical characteristics of symbolism and will then offer a detailed analysis of two important symbolist artworks: one created on the edge of the nineteenth and twentieth centuries, and the other - of the twentieth and twenty-first.

\section{Re-evaluating Symbolism}

In following the aesthetic theory of Alain Badiou (2005), I am taking aesthetic movements and their self-nomination seriously. Badiou describes artistic movements and groups (but not individual artists) as "artistic configurations" and regards them as the main units of art (Badiou 2005: 14). These eventual constellations are organized in series but are not united by any abstract category. In the case of symbolism, such aesthetic configuration centers around the notion of a symbol, but a symbol about which it is hard to determine what exactly it symbolizes. This fits well with the non-categorical unity of the symbolist movement, especially the unity between painting and literature. They are drawn together around the word "symbol," and that is already significant.

Symbolism was severely criticized by the generation of the 1920s. ${ }^{2}$ Today it is often viewed as something that stands dangerously close to kitsch and esoteric mysticism. And if in literature, Mallarmé and Arthur Rimbaud are still considered classics (despite their association with symbolism), such painters as Gustave Moreau, Fernand Khnopff, and Arnold Böcklin have "drifted off" into the background and are relegated to some interval between impressionism and the avant-garde (sometimes they get grouped together as the "postimpressionists"), while Paul Gauguin and early Pablo Picasso are hailed as solitary geniuses who somehow defied all movements. During the Soviet era, Russian symbolist writers such

2 In Russia, the main critics of symbolism were the futurists, in Italy, also the futurists, and in France, the cubists. 
as Blok and Briusov managed keep their place at the center of the literary canon (possibly, thanks to their aesthetic proximity to Socialist Realism), ${ }^{3}$ however they have since conceded to the avant-gardists (the futurists, the OBERIU writers, and a proto-surrealist Platonov) and the neoclassical Acmeists. Meanwhile, it is quite common to misidentify painters: whereas we still group Mikhail Vrubel and Valentin Serov with the symbolists, painters such as Petrov-Vodkin and Chagall are usually left out, even though their alliance with symbolism is unquestionable.

Such suppression is unjust, for it is symbolism that provided the very foundation for future avant-garde and mass cultures. It combined serious intellectual content with a look that made it appealing to mass audiences, all the while keeping open a possibility of making a coherent political statement - something that could not be said about abstract or cubist art.

Symbolism developed in an atmosphere of esotericism and mysticism, which captivated the intellectuals of the late nineteenth and early twentieth centuries. This has discredited it in the eyes of the twentiethcentury avant-gardists and leftists, who have traded magic for political praxis, and soured it for liberals supporting formalist art. Today, exalted spirituality that uses art for the creation of new alternatives to Christian religions is also met with resistance. However, religious feelings often gave rise to vivid images, which remained long after faith and piety ceased to occupy us. In symbolism, moreover, religiosity is accompanied by a feeling that "gods have died" and angels have fallen. The latter suspicion is sobering for it guides us back to the world of inspired, yet quite earthly (and for that reason, somewhat melancholic) characters. As Badiou has recently argued in his discussion of Richard Wagner, we must preserve mystical symbolism's insistence on ceremony (Badiou 2010: 147). ${ }^{4}$ Art will not restore our faith in God, but it will teach us how to be faithful to life's process and to the symbolic rituals that constitute collectivity and preserve meaning despite the absence of transcendental referent.

Nineteenth-century mysticism was in many regards a realization of the crisis of symbolic form in the absence of socially accepted sacral realities: the dissolution of this form would have meant a disintegration of social ties. However, even in our post-secular times, it is impossible

3 On this subject, see Boris Gasparov's lecture at the Smolny Institute of St. Petersburg State University from April 2006. (Unfortunately, the results of B.M. Gasparov's work on Socialist Realism have not yet been published).

$4 \quad$ To cite Badiou's own words: “...I will suggest that the subject of Parsifal is the question as to whether a modern ceremony is possible. The subject is the question of ceremony, and this question is intrinsic to Parsifal. It is distinct from the question of religion. Why? Because a ceremony can be said to have a collectivity's or even a community's mode of self-representation, but transcendence is not an essential condition of it. In fact, we could say that the question posed by Parsifal is whether a ceremony without transcendence is possible" (Badiou 2010: 147). 


\section{Illuminated by Darkness: Two Symbolist Masterpieces}

to maintain symbolic form unchanged. As a consequence, it falls to art to reinvent the cult anew - just as it had been suggested by symbolists as well as by several contemporary artists (we could think of ritual performances by Joseph Beuys, Nam June Paik, Marina Abramović, Viennese Actionists, and, even closer to our time - Christoph Schlingensief). ${ }^{5}$

The name "symbolism" was not a very fitting one. It did not take on right away. As I have mentioned, "symbolism" gained its name from its critics. Émile Zola used the term ironically in 1876 to describe a painting by Gustave Moreau (Mathieu 1990: 9). Jean Moréas’s Symbolist Manifesto followed only ten years later. In this text, the young French-Greek poet suggests the term "symbolism" to replace an even less friendly "decadence." From the 1890s, "symbolism” becomes a commonly accepted term, even though the art movement that it designated would still occasionally be referred to as "idealism" or "ideisme." To the vague style of the impressionists and the murky palette of realists, symbolism opposed the clean lines and saturation that were evocative of the Renaissance and classicism. G. Albert Aurier, a symbolist poet and critic, distinguishes five traits of symbolist painting: idealism, symbolism (expression of ideas through forms), syntheticism (uniting multiple means and forms), subjectivism, and decorativeness (Aurier 1891; Man'kovskaia 2012). And while Aurier emphasizes ideas, Maurice Denis focuses on subjective experience and emotions (1920). Both are, however, pointing out the necessary "deformation" of the object.

Many symbolists (Sâr Péladan and his circle) turn to esoteric hermetic teachings. Most symbolist models first appeared in France, however, eventually symbolist theory and artistic style would spread across Europe and the USA One of the places where symbolism gained particular popularity was francophone Belgium. An entire constellation of fascinating symbolist artists came out of Poland. Stanisław Przybyszewski, the leader of the "Young Poland" movement, espoused mystical ideas that were close to those of Péladan's - he not only proclaimed himself beyond good and evil, but also cultivated Satanism! Zenon Przemyski, an editor of the Chimera journal, the movement's central mouthpiece, would later follow Moréas and Aurier in defining symbol simply as "living analogy" (Cavanaugh 2000: 16-17). Symbolism was also actively developing in Scandinavia. This region had its own mystical idealists (Johannes Jørgensen in Denmark), and its own paeans of suffering and illness (Munch, Knut Hamsun). Particularly characteristic of Scandinavian symbolism is the work of Henrik Ibsen - an earlier author, who applied symbolist idealistic logic to the interpretation of the naturalistic, everyday

See also the discussion of contemporary ritual performances by Genesis POrridge, Bob Flanagan, Ron Athey, and ORLAN in "The Sacrificial Aesthetic: Blood Rituals from Art to Murder” by Dawn Perlmutter (2000). 
life of a bourgeois family (which had destructive consequences for the dramatic form as well as the family).

Despite its apparent assertiveness, "symbolism" is an ambivalent name: after all, it was first used as a critical description of a style that was too divorced from reality (and nature). Negativity, implicitly present in this title was later positively appropriated by the movement itself. "Symbolism" was understood by its founding fathers as a movement that was sublime and assertive, despite its anti-naturalism and tendency for objective and subjective "deformation" (Denis 1920). Although the word "symbol" does not contain any overt negative connotations, the rhetorical negativity pointed out historical negativity: a rejection of realism meant a dissatisfaction with reality and/or alienation from it. A rejection of mimesis was only partial. It presupposed a unity between the negated (as if extinguished) nature and its ideal. Most theoreticians of symbolism point out a double movement: from the sensual to the ideal and back. To quote Sharon Hirsh, symbolism was

an art that would express an antinatural and, in fact, psychological state of existence, but that would also, at least for the next decade, continue to rely on recognizable images from nature as its means of expression. The symbolist artist therefore worked a constant balancing act. To create art that was without reference to nature would have demanded total abstraction, a means of expression that was simply unattainable (and for the most part unthinkable) for artists of the 1880s and 1890s. On the other hand, to create an art in which the images were too recognizable, or came too close to actual "nature," would have negated the true, inner message of the Symbolist (Hirsh 1985: 97).

Symbolists are clearly espousing this dialectic of the material and the ideal from the German Romantics and the idealists of the early nineteenth century.

What do we mean when we speak of symbols? The first thing that most people tend to associate with symbolism is a slightly moldy mysticism or some secret coded image that requires significant erudition to decipher it. However, codes and allegories are more characteristic of the Renaissance than symbolism - think, for instance, of Albrecht Dürer or Hans Holbein. Symbolists borrow their key concept - already as a "ready-made" - from German Romantics (Todorov 1984: 148). Johann Goethe and Friedrich Schelling, who invented the concept of a symbol at approximately the same time, opposed symbol to allegory and used it to designate a particular non-mimetic art, which does not serve to represent external nature but is self-sufficient and that generates a new reality as such. Goethe defines symbolism as that "where the particular represents the general, not as a dream and shadow, but as a live and immediate 


\section{Illuminated by Darkness: Two Symbolist Masterpieces}

revelation of the unfathomable" (Goethe 1998: 47). Schelling, meanwhile, offers a more complex definition of symbol as something in which the movement from the general to the particular and from the particular to the general coincide (Schelling 1989: 46). Both authors point out the balance that exists between idea and sensibility. The balance between the two is a central theme not only for the theory of the symbolic, but for the whole of Romantic aesthetics overall.

Jean Moréas's understanding of the symbolic - when he writes that "symbolic poetry seeks to clothe the Idea in a perceptible form that nevertheless will not be the ultimate goal in itself, but, which, even as it serves to express the Idea, remains subject to it" (Moréas 1886: 1) - completely coincides with that of Goethe. Symbolists were moving very much in the wake of Romantic theory. However, in painting - both with regards to technique as well as method - they manage to offer something radically new.

The Romantic painting often conjures some hazy aura (Caspar Friedrich, J.M.W Turner). Meanwhile, the symbolists of the late nineteenth century assumed a rather realistic approach to representing life with the sharpest and clearest of lines. At times, life in symbolist art appears as adorned and brightly lit; at others it is mysterious, somber, and inhabited by mythological and fantastical creatures. The latter are sometimes painted in a naturalistic manner (for example, the saints on the PreRaphaelite canvases are robust peasant girls; Jacek Malczewski meticulously details his harpy's armpit hair, Gustav Klimt does the same in his female portraits - all of that is very typical for the movement). ${ }^{6}$ But sometimes fantastical beings are represented as disembodied luminous stains. The faces of these creatures are idealized, inspired (with either angelic or demonic passion), and, more often than not, shrouded with sorrow. Symbolist painting is saturated with eroticism, which is strengthened

by

its combination of pornographic naturalism with the idealization of a landscape/face or demoniacal narcissistic desire. Many symbolists would prepare their canvases with special textured grounds, so that the heterogeneous materiality of their surfaces would be all the more noticeable behind the ephemeral forms (Heller 1985). Reinhold Heller (1985) justly explains this effect by the "dialectics" between the material and the abstractly ideal, so characteristic of symbolism.

The way the Symbolists work with color is quite special: they use highly contrasting colors that often look unnatural and include a dark component. Gaugin, the father-founder of the French symbolism in paint-

6 Malczewski, Jacek. Chwila tworzenia - Harpia we śnie (1907). Частная коллекция. URL: http://www.pinakoteka.zascianek.pl/Malczewski_J/Malczewski_J_7. htm. 
ing, instructed his disciple Paul Sérusier: "How do you see that tree? [...] Is it really green? Then put it down in green - the most beautiful green in your palette - and that shadow is rather blue? Don't be afraid to paint it as blue as possible" (Gibson 1995: 45). We see that this particular method is not just distinct, but even contrary to Impressionism with its continuous palette.

Symbolists stand out among the artists of their time thanks to their obsession with the fantastical and the pervasive melancholic mood of their artworks. Even though movement's founders strove to distance themselves from the decadents, they ended up espousing, almost despite themselves, the eroticism and spleen of the latter. Despite "officially" renouncing decadent hedonism in favor of idealism and mysticism, symbolist art remained profoundly melancholic. The fact that the symbolists did not fully overcome decadence sets them apart from the Romantics, from whom they borrowed most of their theoretical positions. What we are dealing with here is a polarization of the symbolic and a sense of worldhierarchy. For many symbolists (Gustave Moreau, Aubrey Beardsley, Oscar Wilde), ideal beauty needs evil to overcome nature. Hermetically minded symbolists such as Péladan followed the Neo-Platonic doctrine, founded on the dialectic of body and soul. Ascending to God and Spirit paradoxically requires humans to self-destruct: this is the origin of the satanic motifs in symbolism and the dark ways in which the Spirit reveals itself in nature. Held against the eternal light, all sense-perception begins to appear sinister - as a "night of the world."

Among earlier Romantic and idealist authors, it is Hegel who was most attentive to negativity. As I mentioned earlier, the symbolists absorbed the Romantics' idealist theory of the symbolic. Thanks to existing translations, they had access to the works of Goethe and Hegel. For instance, Mallarmé has reportedly either read Hegel or knew of Hegel's works (Conio 2003: 43-65). Symbol for Hegel is a sensuous object that does not coincide with itself and is therefore incomprehensible, negative, and is denied its proper meaning (Hegel 1975: 299-426). However, thanks to this very negativity, it does not get dissolved in the idea, but acquires a certain material density thanks to its very obscurity. Mallarmé thinks along very similar lines when he emphasizes the negativity and opaqueness of words. (Take for instance his miniature "La Pénultième" [Mallarmé 1977: 116-18]. The esoteric word-symbol plays with both the semantics - nul, nothingness, zero - as well as with the feeling of the approaching end of the world or century. $)^{7}$

According to Hegel's Aesthetics, symbolic art (primarily, Egyptian and Hebrew) - is an art that does not know what it is expressing (1975: 354).

There are no citations from Hegel in Mallarmé. The philosopher's influence on his work was indirect. 


\section{Illuminated by Darkness: Two Symbolist Masterpieces}

Negativity, because of its lack, uses "symbols" as undeciphered, mysterious images, which do not coincide with themselves and do not have a clear meaning. Even in instances when allegorical correspondences could be established, symbols in symbolic art remain undeciphered (or only partially deciphered). This is the reason behind the popularity of Egyptian, Biblical, and fantastic themes. Egypt for Hegel

is the country of symbols, the country which sets itself the spiritual task of the self-deciphering of the spirit, without actually attaining to the decipherment... Egyptians, amongst the peoples hitherto mentioned, are the properly artistic people. But their works remain mysterious and dumb, mute and motionless, because here spirit itself has still not really found its own inner life... (Hegel 1975: 354)

For the Romantics and symbolists alike, a symbol contained a high concentration of esoteric elements - this put it dangerously close to the sphere of elite, secret knowledge that could be deciphered and attained only by the initiated few. However, the distinction between allegory and symbol was never quite clear to most symbolists, and many of them believed in various gnostic codes. A more sober, technical notion of symbol for the symbolist and post-symbolist tradition of Mallarmé, T.S. Eliot, and Eugenio Montale has been offered in our time by Umberto Eco: "Sensitivity to the symbolic mode stems from having noticed that there is something in the text that has meaning and yet could easily have not been there, and one wonders why it is there" (2015: 153). Therefore, "the symbolic mode exists at that point where we finally will have lost the desire to decode at any cost" (Eco 2015: 160). If we recall the theme of the "interlocutor" among such dark twentieth-century visionaries as Osip Mandelshtam and Paul Celan - it will bring us back to the heart of the symbolist problematic. If the image is obscure or coded, it does not mean that it is a purely formal one. It is just that its meaning is lagging behind and is in need of further discussion and analysis in the future.

Symbolist painting is characterized by plots and thematicity. Symbolists writers also do not hesitate to portray ideas-as-such. In the words of Pierre-Louis Mathieu,

What the Symbolist writers and artists indeed had in common was the fact that, by means of words, forms, colors, they sought to communicate to the reader or viewer a personal message of a spiritual, moral, or even religious nature. The Impressionists and Naturalists, on the other hand, had contented themselves with merely reproducing the physical world. (Mathieu 1990: 22) 
This is a programmatic, ideological art $-\mathrm{a}$ fact that contributed to its relative suppression from history. As Philippe Jullian noted already back in 1971, "When dealing with the painting of the period from 1880 to 1910, the experts mention a score of artists, from Seurat to Matisse, without ever saying what they owed to masters who are ridiculed because they attached importance to ideas" (Jullian 1971: 15). And when symbolist artists do succeed in attracting the attention of a mass audience, then we tend to see Vincent Van Gogh and Gauguin - the less complex and most "realist" representatives of their generation of symbolists, and even they are more often than not grouped with the so-called postimpressionists (a euphemism that was invented in the 1910s).

Natural attractions of a slightly chthonic kind occupy a prominent place among symbolist subject matter: Symbolists frequently exploit sinister sexuality, rituals, violence, and sickness. The dark side of life is aestheticized. Michael Gibson, author of one of the more synthetic texts on symbolism, believes that symbolism is defined by a negative disposition of the mind. He lists the attributes of the "depressive climate" so typical for many symbolist works: "The season most often referred to is autumn; the favored hour, dusk (or night); the dominant element, water (rain, the canals); the reigning heavenly body, the moon; the state of mind, sorrow and ennui; the sexual climate, disillusionment and impotence; the mood, weariness and anticipation of death; the social situation, solitude" (Gibson 1995:17). While melancholia is also found in other aesthetic movements, Gibson believes that for symbolism it is an essential and crucial element. It needs to be added that negativity, that in symbolism is present on the level of themes and content, in modernism and in the twentieth-century avant-garde comes in on the level of form, while the range of themes and motifs widens and becomes more varied. Expressionism tends to reproduce symbolist melancholia, but cubism, Fauvism, suprematism, and, at times, even surrealism tend to be more positive and optimistic. In modernist literature, however, negative tone remains the dominant one and the continuity with symbolism remains unbroken. (For instance, the symbolist aesthetic of somber philosophical fantastic fiction quite naturally flows into Franz Kafka's prose, Eliot's poetry, and even Jean-Paul Sartre's literary texts.)

We should now consider symbolist art's negative plots (according to Hegel's logic of negativity, the symbolic in these plots is akin to a pyramid erected over a grave). These are: the theme of the demonic, the symbols of temptation, sin, and death (harpies, female sphynxes, etc.). Another common motif is the melancholic, sedate, yet soothing and beaconing mood of a desolate island-adrift-in-the-center-of-the night, which is usually conveyed by a saturated blue color. Portraying important characters as darkened silhouettes that serve as screens for the projection of an 


\section{Illuminated by Darkness: Two Symbolist Masterpieces}

evening light, is another typical symbolist technique called contre-jour. ${ }^{8}$ It was not invented by the symbolists but was widely used by them, especially by French and Belgian artists (for instance, Alphonse Osbert, Georges Lacombe, and William Degouve de Nuncques). From a philosophical point of view, what is important here is the inversion of the function of light: it is as if the figures are illuminated from the inside by the "black sun" of melancholy. These dark figures create for the viewer an effect of looking at one's own back, at being included into a painting as the source of an invisible gaze. Such is the aesthetic embodiment of the negative dialectics: inversion of light, dark tones, and melancholic mood allow the symbolists to create images that are simultaneously idealized and sensuous. An angel, growing darker as she falls, is acquiring flesh.

The symbolists also use black color to darken other colors or to offset their luminosity. Sometimes figures emerge directly out of a dark stain or grow back into it, creating an ornamental play between the foreground and background (we can see this effect in the works of Klimt and Wojciech Weiss). It is important that the symbolists move toward abstraction, but choose a different route than the impressionists, who insisted on the dissolution of form. The symbolists introduce abstraction through darkening, through elliptical erasure of separate elements. This allows to project a viewer into these dark fields and to convey the fullness of life by contrasting it with the darkness of the night that envelopes it. Images become saturated with intensity to such a degree that that they begin to morph and bend - artwork itself becomes a portal onto the sublime, a symbol of a door into a new life. The best example of this is G.F. Watts's masterpiece The Sower of the Systems. ${ }^{9}$ In the twentieth century nothing has approached the saturated intensity of Mallarmé's sonnets, with the exception of, perhaps, classic rock music where the intense bass sound is analogous to the dark color in symbolist paintings.

Rather than the mere expression of subjective feelings, the symbolists strove to find in their art their correlate in nature and in fantasy. The same thing could be said of impressionism, but whereas in impressionism subjective feelings were supposed to be coming from nature, symbolism moves from subject (or from an idea) toward an object. On the one hand, the desire for materiality is stronger in symbolism than it is in impressionism - that is why symbolists often gravitate toward a classical, realist style. A contrast is produced between the clarity of the image and its symbolical ambiguity and negativity. On the other

$8 \quad$ See, for example, Georges Lacombe’s La Mer jaune, Camaret (1892). Musée des Beaux-Arts, Brest. URL: https://curiator.com/art/georges-lacombe/la-mer-jaunecamaret

9 George Frederic Watts. Sower of the Systems (1902). Watts Gallery Collection, Guildford (UK). URL: http://www.wattsgallery.org.uk. 
hand, thanks to their symbolism, figures can stand out of their context. The "symbolic" perspective allows a greater freedom with combining images, gradually making them more autonomous. Symbolism actively draws on the fantastical: it inscribes into the world that which is absent from it and what is only imagined. Imagery becomes literal: nominally familiar fears and dreams (angels, demons, hypersexual objects) acquire a physical appearance - as if we were always supposed to imagine them looking that way. This deadpan, hyperbolic literalness sometimes puts symbolism in a dangerous proximity to kitsch.

It is the palpability of images and the physicality of the symbolic that distinguish symbolists from the impressionists and their experiments, becoming meaningful only in combination with ideal or mystical significance. Materiality here does not correlate to "reality." It regains its philosophical significance as "matter" or a "meon," to use the Neo-Platonic term that would later be adopted by Minsky. The sublime meaning thickens and becomes non-transparent among dark matter that is alien to it but very much palpable. In this sense, symbolism is a dialectical synthesis of realism and the fantastic. Such synthesis does not dissolve their antinomy, but rather organizes this tension into a form of dynamic unity. The central aesthetic question in the nineteenth-century Realist and Romantic art was this: If art has a right to exist, then it should enter into life or, on the contrary, absorb reality into its aesthetic sphere. Symbolist art is marked by this question and by the sorrow at the impossibility of following the first route. It takes the second path and constructs a special mechanism that allows art to function as an absolute object. This creates an effect of reality as of a fantasy that came true.

In the Russian context, the critique of symbolism by the Acmeists primarily, by Nikolay Gumiliev and Mandelshtam - is well-known. The Acmeists maintained that symbolism posited an "uncertain," contingent reality: a rose was shown as giving a nod to a girl, a girl was nodding to a rose, and neither was revealing their individuality. The Acmeists, in turn, were defending neoclassical ideology on the grounds that one had to keep mystical silence about all divine and sacred matters and to only hint at them without including them directly into art. As part of this polemics, in 1912 Mandelshtam articulated a nearly existentialist program in which he emphasized the importance of reality and being-as-such for art: "There is no equality, no rivalry, only a community of co-conspirators united against emptiness and oblivion. One should love the existence of an object more than the object itself and one's own being over oneself - this is the commandment of Acmeism." (Brown and Mandelshtam 1965: 50).

The question of what should be considered reality remains. The symbolists were placing their bets on the higher reality of the ideal, on the realiora. However, a disembodied idea cannot lay claim to reality. 


\section{Illuminated by Darkness: Two Symbolist Masterpieces}

Already in 1904, Korney Chukovsky in his response to Przybyszewski, the leader of the Polish symbolist movement, brilliantly commented on the negative attitude to reality that characterized symbolist art:

There are such moments in art's life when it seems to have grown tired of creating. It appears to no longer have the force to shape a coherent and unified sense of life with colorful images. It then starts to scrape at these images, searching for something absolute, impermeable, and timeless, something that it itself used to clothe in beautiful forms. [...] All of them are searching for the tragedy of the collective soul, the tragedy of something that mysteriously dwells under the temporary masks. [...] In their efforts to find it, they rob reality of its luster, strip it of time and space, from contingency, from itself, from its warmth and blood from everything... And the tragedy of such art lies in the fact that these accidents, these colors, this diversity are exactly what it is searching for. Accidents point to the greatest consistency; the external contains everything inner. [...] But they go on searching among the abstractions - that is why contemporary art no longer creates joy, but only suffering... (Chukovsky 1904).

Anxiety brought on by such a taking leave of reality was thematized by symbolism itself. This anxiety pointed at a regrettable illusory quality of the images produced by art and aimed at projecting them back. Blok's self-critical Puppet Show deals with the "unmasking" of symbols as "cheap and artificial" and poses a question about how real and un-mystical love is to be portrayed (Blok 2003: 19-33).

On an intuitive level, such criticism seems correct: it is disappointing to read or look at artworks that are in the business of self-denunciation and that declare that what has been read or viewed is all raging madness and a crude entertainment. We usually want artworks, especially those into which we "sink" considerable time and emotion, "to play fair." Of course, one could say that art portrays the haze and impermanence of the everyday world and offers a position from which it could be regarded from the viewpoint of the absolute. Shouldn't we, to use an Acmeist expression, dispel all this fog, and instead use the opened perspective onto the absolute to artistically affirm the earthly existence of singular things? To that, the symbolists would have answered that the symbol for them is not a rose that gives a nod to a girl, but an object that, thanks to its symbolic meaning, becomes self-referential and that, therefore, is complete and self-sufficient. A "good" symbol - a mirror, a fair lady, a doll, etc. - does not signify some individual thought or thing. Thanks to the plurality of meanings that it contains, it amplifies its own manifest being by becoming more concrete, richer, and stronger than the simple facts. The disincorporation belongs to the symbol only as a moment 
(in the Hegelian sense of the word), and the true real being is not existence, per se, but the meaningful being of the symbol. We can find examples of this in the works of the Acmeists themselves - on closer consideration it turns out that their preference for the "existing" objects is thoroughly symbolic (giraffes, trams, stones, horseshoes, etc.). However, both groups see clearly that "the struggle" for being, to use the expression from Heidegger (2000: 111), is an inherent theme of art. Martin Heidegger (2001) himself constructs an aesthetic close to the symbolists: its paradigm consists of objects that do not symbolize anything besides themselves and that carry within themselves their own emptiness: a temple, a chalice, a bell. Heidegger's archenemy Adorno too espoused, in a way, a symbolist aesthetic. As is well-known, Adorno (1970) considered as authentic only those works of art that embodied their own negativity, that is, which embodied their own failure to become a real embodiment of either the dream or a nightmare that produced them. Once again, we are dealing here with a type of object that becomes all the more tangible and material as a result of the disintegration of existence.

Vladimir Nabokov, a successor to the quarrels of the 1910s and 1920s, had his finger on the pulse of Russian symbolism better than others - almost all of his novels are characterized by a certain movement toward derealization. Realist narrative in Nabokov inevitably begins to falter, and eventually becomes impressionistic, revealing some hallucinatory details. It encourages the reader to conclude that everything that happened was just a fever dream and reveals all things as "transparent" - as per the Acmeists' critique. It is possible that Nabokov is projecting those same symbolist poetics onto the Russian Revolution that he famously rejected, creating a pessimistic world of vivid images, illuminated by the light by the triumph of extinction. In contemporary literature, this device has been borrowed by Victor Pelevin, whose novels are often organized around a series of awakenings - when somebody wakes up from somebody else's nightmare or when somebody exits virtual reality. (It isn't an accident that one of the characters in Pelevin's Chapaev and Void ${ }^{10}[1996]$ is a symbolist poet.) It is true, though, that Pelevin does not share Navokov's pessimistic nostalgia. What we encounter in his novels is sublimation, a cult of personality of a lonely artistic genius who can both create and destroy entire worlds. At the same time, Pelevin's prose also contains moments of a very precise social realism: every instance of mystical zombification is a metaphor for a relation between power and opposition, and all mystical symbols and things - are but projections of capitalism's fetishism of abstract substances like money, oil, or drugs. In one of his recent novel entitled S.N.U.F.F. (Pelevin 2016), money is called "manitu": it is simultaneously a god, a currency, and a monitor. This is a classical symbol, how-

10 Published as Buddha's Little Finger in the US and Clay Machine Gun in the UK. 


\section{Illuminated by Darkness: Two Symbolist Masterpieces}

ever its sacral character is treated ironically and the plurality of its meanings allows the author to unify and organize the otherwise fragmented perception of the contemporary person. We will see how in the works of Jacek Malczewski, multiple meanings similarly get condensed into a single image.

Considering that this article is about art, the influence of the author's own taste is unavoidable. Therefore, I will state right away that I consider symbolism taken broadly - from Wagner through Secession to Proust as one of the apexes of Western art (I am not alone in this, as it appears that Badiou shares my opinion - most of his philosophy revolves around examples drawn from Mallarmé and Maurice Maeterlinck). I will list my previous arguments. First, symbolism is an intensive and effective art that depicts and expresses negative characteristics of modernity. It practices negation both in the abstract sense of erasure but also in the concrete sense of depicting counterimages and counterforces. Therefore, unlike abstract painting, symbolism never becomes nihilistic. Second, symbolism is a dialectical, synthetic, and balancing art that tentatively unites figure and ornament, idea and its physical incarnation. Third, symbolism forces us to consider the real as a union of ideas and matter.

In what follows, I analyze two eponymous artworks, created one hundred years apart. Both are entitled Melancholia. Both attain a sublime aesthetic effect through a hyperbolic portrayal of negation. Their characters are defeated and perish without any apparent cause - through psychological reasons alone. However, what stands behind their failure is an $o b-$ jective catastrophe. This catastrophe becomes concentrated in an expressly artificial, fantastical symbol. The form of both works is fraught with tension, complicated by reflection; its proportions and genres are askew. This, however, does not result in a rejection of figurativity. On the contrary, the very tension and distortion become the central subject matter and are materialized in a symbol.

\section{Jacek Malczewski's Melancholia}

Jacek Malczewski, a painter and the recognized leader of Polish symbolist artists painted Melancholia in Kraków in 1890-94. ${ }^{11}$ The work won initial fame in 1900 when it was shown at that year's World's Fair (in the absence of Polish pavilion, it was exhibited in the Austro-Hungarian one). This is also when it acquired its present title: the original name

11 Malczewski, Jacek. Melancholia (1890-1894). Muzeum Narodowe w Poznaniu, Poznan. URL: http://www.mnp.art.pl/en/. 
was A Prologue. A Vision. The Last Age of Poland. Tout un siècle, but when in 1900 a critic suggested changing it to Melancholia, Malczewski did not object.

The painting is energetic and saturated - both in its composition and color. Its intense expressive energy is immediately arresting. Thanks to the asymmetrical and sharply tilted perspective, its volume is open, pulling the spectator's gaze into its spiraling vortex. ${ }^{12}$ To describe it in the most direct and simple terms, one could say that it shows the artist's studio, where we can see:

- The artist himself, painting (in the background).

- The images from this "painting within a painting": they begin to float out of their frame and into the space of the studio, filling up the "real painting" in front of us. These images show an incredibly dense crowd, so dense, that it is almost impossible to distinguish the individual people in it. They are carrying spears. The people in this group are young at the start (on the left): they are brightly lit but are painted in a rather quick impressionist manner. The figures at the end (on the right) are darkened but are distinct and realistic.

- A window on the right edge of the studio, toward which everyone is rushing.

- Idyllic nature outside the window.

- A woman standing outside this window. She is dressed in black and is either recoiling from the idyllic sight behind the window or is preventing the crowd from escaping through the window.

- In the foreground - a table with the painter's tools and (once again) the artist himself, now shown as one of the men in the crowd.

What we have here is a closed structure - "a dream within a dream," to borrow Jan Cavanaugh's description (2000: 192). We are shown the process of creation of this very painting. The viewer is forced to look at it from the point of view of the artist working on it. The painting within a painting shows the three unsuccessful Polish uprisings of the nineteenth century and the three ages of man. In this manner, two motifs are overimposed and are made to comment on each other. These are, first of all, the images swirling around in the artist's mind and escaping into reality just to find themselves - once again - within the space of art. The second motif deals with the Polish revolutionaries, trying to escape the vicious circle of foreign occupations and to gain freedom, but getting

12 “Malczewski's figures with their firm volumes [...] might pass muster in a provincial art academy, and his perspective illusions are based on traditional training. But these components are stretched to breaking-point, with palpable figures now deying gravity in their collective tornado of passion and gloom and with the ledge of the window rushing from near to far at a vertiginous speed and tilt that create, with stillrational tools, a space with still-rational tools, a space for dreams and nightmares" (Rosenblum 2000: 36). 


\section{Illuminated by Darkness: Two Symbolist Masterpieces}

defeated and remaining trapped in the closed antechamber of time, incapable of transcendence. Judging from the presence of the woman dressed in black - a representation of melancholia - the defeat that they suffer is at least partially due to their own fault, for they are actually afraid of freedom, afraid of stepping outside into a dream that they are striving for.

The fate of an artistic image as a dream that is trapped within an artwork, but that wants to break free from it, is juxtaposed here with the fate of revolutionaries, whose militant negativity suffers defeat and remains only a negativity that fails to advance into the utopian future. Both paradox and tension are obvious here. If we were to consider the situation of the artist himself and think of this painting as his self-reflection, then, to quote Jan Cavanaugh:

Malczewski was divided between his desire to follow Matejko [his teacher] as a spokesman of the nation and a loss of faith in the mission of national art, which seemed futile to him. Melancholia expresses the artist's feeling of powerlessness and comments on the impossibility or "decadence" of the national situation and the vicious circle in which the Poles were bound up this time. (Cavanaugh 2000: 194)

Andrzej Pienkos agrees with this analysis. He sees in Melancholia primarily a work of "automatic" art that belongs to a long tradition of artists depicting their studios to show the resistance exerted by the images against the will of their creator (Pienkos 2002: 45-57). At the same time that Malczewski is invoking the most famous painting of this type - Gustave Courbet's Artist's Studio (1855) - he is polemicizing with it. Whereas Courbet offers an apology of art and states his faith in the attainability of artistic dreams in reality, Malczewski, with a double gesture, emphasizes the border that separates imagination from reality: by creating a distance between the viewer and the painting, he, at the same time, is encouraging the characters as well as the viewer to break it (Czekalski 2002: 96).

All of this brings us to the well-known subject of melancholia, which has occupied artists and thinkers for a long time. One of Malczewski's most classical allusions is Dürer's Melancholia: it too has a window; the futility of revolutionaries' efforts corresponds to the theme of vanitas represented by the instruments that we see on both images. The border between art and reality in Malczewski painting is guarded by a mysterious woman clad in black. If we were to speak of the painting's "symbolism," she is its main symbol. She is an embodied "no" that has come to life as a symbol of melancholia and negativity, of the impermeability of borders and the inexhaustibility of meaning - that is, if we are to follow Hegel, she is a symbol par excellence.

It isn't just that revolutionaries are trapped in their unfreedom like fantasies within one's soul, and it isn't that both - the dreams and 
the revolutionaries - are yearning for liberation and are equipped with essential negativity (spears). What is significant is that this artwork is striving to reach a reality that would surpass the mere reality of illusion. To achieve that, it must revert to self-criticism and self-reflexivity. Revolution and its defeat are regarded not only on the level of content, but form and expression as well. This endows its characters with life - for it is form and not content that constitutes the empirical reality of an artwork. To be more exact, reality here lies in the relation between form and content. In Malczewski's painting, this relation is isomorphically doubled. On the level of content, we are presented with the very same conflict the conflict of content and form - that determines a concrete factuality of every painting. Reflexivity and self-criticism are not just forms of autophagy, but a way of revealing history within an artwork. In this manner, the central question of symbolism, that would later also become the central question of modernism and the avant-garde, coincides with the main political question of the present time.

Modernism or the avant-garde? The choice is between an autonomous work of art and a desire to bring art into life - something that requires art's self-criticism. Both ends can be achieved through reflexivity and irony, through an interrogation of the mimetic function of art. However, the solutions may be radically different. Malczewski is a symbolist, which, at first thought, seems to align him with modernism. However, we clearly see that he has doubts about the modernist aesthetic solution: the autonomous, absolute work of art that represents itself through itself, and with it - the entire world (or, at least, Poland) - in his interpretation is a locked trap. Images that fly from the canvas out into the world are not just fantasies - Malczewski wanted to inspire and serve the cause of Polish liberation (that is why the original title of the painting includes both the "Last Age of Poland" and "The Prologue"). He points out the limitation of art and sets an intention to overcome it. An avant-garde impulse is present here negatively: the images are merging into a unified swirl, they are on the verge of disintegration. As a result, Malczewski's painting is a representation of itself alone - it is an image about the process of producing a painting. In its extreme limit, it is therefore free from external content.

In Melancholia, we witness a collision between two competing intentions - the tension between its centrifugal and centripetal movements produces a real forcefield. Here a window into the world to which painting is traditionally compared (from Leon Battista Alberti to Marcel Duchamp) is pushed to the side. Normally, a landscape seen through the window in Renaissance paintings (for example, in Leonardo da Vinci) functions simultaneously as a backdrop for the figure on the foreground and as a symbol for a painting itself being a kind of a window into the world. Malczewski's landscape, however, presents an unattainable utopia - it could be 
a dream or some higher reality. It also decenters the composition, transforming all other elements of the painting into a shadow or a background. Rather than look out of the window into the outside, and, consequently, into an artwork and into the world, we are gazing from within an artwork onto an unreachable external world. The mimetic relation between the painting and its model is twisted inside out.

On the foreground, we see a spiraling crowd that "twists" a viewer (as well as a painter shown on it) into the painting. Not finding a release for this tension, the movement begins to swerve in the opposite direction. The mass of people should have been able to reach the viewer and the artist, but not having found their way there, they made a turn and swerved to the right, toward the window of utopia and melancholia. This collision has a political dimension that is not reducible to the Polish question. Almost all of the nineteenth-century revolutions were unsuccessful (and not only in Poland): even if they succeeded with a negative breakthrough, they failed to build a new society. At best, they accomplished the institutionalization of negativity in the existing state. In the twentieth century, the situation changed, even though then, too, negativity (terror and melancholia) prevailed over the Ideal. What is revolution striving for - for the creation of a "demonstration democracy" (Etzioni 1970) inside the state or for a construction of new society premised on the permanent heroic yearning for difference? In the twentieth century, revolutions followed the former trajectory. And it is this trajectory that corresponds to the movement of Malczewski's revolutionaries trapped in their immanence. But good old transcendence is waiting for them by the window nevertheless.

\section{Lars Von Trier's Melancholia}

Michael Gibson, a leading scholar of nineteenth-century symbolism, remarks that the decline that befell symbolism in painting and poetry in the 1910s coincided with the rise of cinema. Gibson believes that cinema has absorbed many characteristics of symbolism: its dark atmosphere, its monsters, its fascination with the psycho-pathological, with detective mysteries and Wagner's music, and so on (Gibson 1995). We should note that this continuity has not only a historical and chronological explanation, but also an objective reason behind it. Symbolism was an attempt at literal realist depiction of the symbolic. And cinema, based as it is in the movement of photographic images, is doomed to realism even when the tasks that it places before itself may be modernist. Unlike the cinema, twentieth-century poetry and painting rejected representational verisimilitude and, in doing so, radicalized the destructive impulse that was initially introduced by symbolism. 
Von Trier's Melancholia (2011) shares with Malczewski's painting more than just a title - the film wears its allegiance to symbolism on its sleeve. As in his other films, in Melancholia, Von Trier follows the tradition of Henrik Ibsen, the major Scandinavian symbolist of the early twentieth century. The film contains many references to symbolism: Wagner's music, a fascination with evil, a visual citation of a John Everett Millais painting (who was a Pre-Raphaelite and therefore a pre-symbolist), mysterious carnal symbols of the planet Melancholia, horses, wigwams, a plethora of cultish, ritualistic, and openly mystical elements, as well as an inclusion of a spectator by means of the vivid self-referential metaphors for cinema-viewing (an optical "device" that a little boy, one of the film's characters, invents to watch the movement of the planet that, once it finally arrives, comes to fill the entire screen). In one of his interviews, Von Trier says that among his methodological principles used in Breaking the Waves was to treat the genre of melodrama with maximal realism (Thorsen 2013). I would venture a suggestion that Von Trier is a neosymbolist and that his popularity is something of a déjà vu from the fin de siècle of a century ago. Von Trier, it should be said, supplements the symbolist tradition with avant-garde or even postmodern elements such as the hyperbolic (Thorsen 2013), overdoing nightmares and misfortunes and overtly manipulating the spectator's emotions. Here, Trier surpasses the limitations of a modernist artwork (that tends to remain autonomous and distant from the rest of life) by reverting to kitsch and mass-art tricks. However, what he is trying to achieve by this is to surpass art's limitations and to express, from within art and perhaps even despite art, something "real" - a catastrophe that is imagined so vividly, it begins to acquire tangible outlines.

The film begins on the wedding day of a character named Justine, who, we are told, works as an ad executive. Justine suddenly grows profoundly depressed at her wedding and her marriage dissolves during the night of the wedding party. Her behavior bears marked symptoms of melancholia (among other things, she suggests an ad campaign for an object that would be branded as "nothing"). Living in a superficial bourgeois society filled with empty rituals and disingenuous emotions, Justine begins to feel as if the world was slipping from beneath her feet. This experience of the "loss of the world" finds its allegorical and literal fulfillment in the second part of the film, during which Justine, together with her sister and the sister's family, are watching the end of the world. The wandering planet Melancholia crashes into Earth and destroys it right before their eyes.

Melancholia here is not just an emotional affliction, it is a mood that is formative of an artistic soul. It is typical of many artworks that rather justifiably mourn the heavy human lot. Von Trier borrows several motifs from Dürer's famous Melancholia (1514): the proximity of a mysterious 


\section{Illuminated by Darkness: Two Symbolist Masterpieces}

star - a comet or an exploding meteorite - watched from a picturesque bank of a river, a young woman's emotional numbness, multiple optical devices and mathematical calculations. ${ }^{13}$ Von Trier also draws from Sigmund Freud's well-known theory of melancholia: whereas for Freud, the lost object casts a shadow on the subject's ego (Freud 1957: 249), in von Trier's film the strange planet "casts a shadow" over Earth. Considered this way, the film appears interesting, but, potentially, derivate - yet another Nordic saga of European nihilism and Western depression.

However, it has yet another, less obvious theme. ${ }^{14}$ The protagonist tells her sister that she knows that life does not exist on any other planet besides Earth: "We are alone in the universe." Justine not only avoids people, she also enjoys her narcissistic solitude (as when she leaves her wedding party to take a bath or when she undresses and masturbates in the light of the deadly planet). Justine is very close with her sister Claire. There are several scenes of the two women caressing each other. Claire is pensively watching Justine when the latter is stroking her breasts illuminated by Melancholia's light. The fact that each of the film's two parts is named after one of the sisters emphasizes the importance of their relationship. By the end of the film, there are only the two of them and Claire's young son to greet the deadly arrival of Melancholia. (They attempted to escape, but "you cannot escape from Earth." The theme of claustrophobia was, of course, also important for Malczewski, with his trapping of ghosts in the artist's studio.) A planet - blue and identical to Earth - crashes into it, we see an explosion wave, and the light goes dark.

It appears that what the director is after is more than just a problem of the loss of connection between a person and an object. Rather, it tells a story of excessive self-identification between the protagonist and her sister, whose presence sends her into an erotic and mimetic crisis. Unconscious incestuous attachment here is combined with mutual identification accompanied by sibling rivalry (love toward one's double is a favorite subject of Jacques Lacan and Renais Girard). Justine's melancholy is caused not so much by the loss of the world (in fact, she seems glad to lose it), but by the suffocating presence of the Others, as well as by the traumatic combination of her own narcissism and her incestuous desire for her sister (whom she loves narcissistically, as her alter ego). The film demonstrates the complexity of the "ego" - whether it has been abandoned by the world or not. Ego must become entangled with the Other, and every attempt to isolate oneself results in a paranoid catastrophe (the blue planet Melancholia pursues the Earth and destroys it at the end).

The main intrigue of the film - the relationship between the two

13 The film mocks the pretentiousness of natural science that often makes wrong predictions.

14 See my analysis of the film (Magun 2011). 
sisters - is doubled by the relationship between the two planets. This corresponds to the objective structure of reflection. Earth encounters its twin sister who casts her shadow over the other. The characters watch the approaching planet through an improvised device - a ring that should but does not contain Melancholia in its frame. This is a clear reference to avant-garde art with its desire to move beyond the frame and enter life. A direct collision with an image may be dangerous: "objects in the mirror may be closer than they appear." Art can not only frame and distance reality, it can also bring it closer, making what has appeared as innocently "aesthetic" step out of its frame and enter the life itself. This is especially dangerous in the case of mimetic reflections of reality, that is, when a viewer must recognize herself and her world in the film: mirrors as well as telescopes are often used in art as tools of narcissistic melancholia.

The speculative, reflexive structure of this film as well as the relationship between the two sisters offers a self-referential metaphor for the very form of cinema. Art is a speculum mundi, it may also become a deadly ghost of numbness (as in Lacan's "Mirror Stage” [1949: 449-55]). Being simultaneously a world's "mere image" and its double, artwork can trade places with its model and return the gaze (for instance, in Plato it is not the artist who must imitate things, but the things that should imitate an idea). In Von Trier's film, everyone (besides the protagonist) are busy consoling themselves that the world would not be destroyed, that the evil planet would "fly by." We can read in this a parody of those who treat art as innocuous, as a zone of special license. ${ }^{15}$ But the planet escapes the frame and crashes right into the spectators: as it is rapidly approaching Earth, it gets to fill the entire screen, forcing us to remember the scale and materiality of the screen itself. As is with Greek tragedies, this spectacle deprives its audience of their alibi, it catches them unawares and vulnerable at a point, when they were hoping to remain as distant "egos" - to remain melancholic moviegoers, idly searching for entertainment and impressions. To present the audience with the problem of reality, the film demonstrates its destruction.

Art questions and probes the reality of the depicted things and their materiality, but it does not stop at that. Aesthetic act may be compared to a ritual that is performed with insufficient seriousness, as if in gest. The central theme of this film (as well as of Von Trier's several others) is an unsuccessful, interrupted ceremony (in this case - a wedding). ${ }^{16}$

15 See "Museum Songspiel," an ironic film by the Chto Delat? collective, in which illegal workers put on El Lissitzky's costumes and go to hide in the museum as their last refuge. Chto Delat? Museum Songspiel. https://www.youtube.com/ watch?v=9dYTCfK68Sk.

16 The theme of a ruined celebration is very important for von Trier's work overall. For instance, it has found a brilliant realization in his script that Tomas Vinterberg used for his film, The Celebration (1998). The film's protagonist successfully ruins 
And yet, art is not quite a ritual, not even a semi-ritual. In fact, Girard rightly maintains that art is born out of a crisis of ritual. Unsuccessful ritual, or, rather, the impossibility of a ritual in contemporary society, emerges as the film's central theme. It is in the space of a botched ritual of wedding that the symbolic value of things is suspended and that the aesthetic process takes place. However, at the end of the film, the characters perform yet another ritualistic magic gesture: together they build an improvised wigwam that is meant to keep them safe in the midst of catastrophe. And although their plan is bound to fail, we get an impression that unlike the wedding, this ceremony does become a successful symbolic gesture that grants strength and dignity to the perishing characters and film viewers alike. In this way, art that in itself does not have reality and therefore goes searching for it suddenly gains this reality in a moment of catastrophe - during an event that mirrors art's own negativity.

The tension within Von Trier's film is created not only by the melancholic mood and the expectation of the end of the world. It also comes from a collision of several rather concrete forces and principles. What stands behind the abstract negativity is its actual opposite - that is, resistance. The negativity of the fin de siècle is not born out of nothing but out of the struggle between several different real forces.

The contrast between the two sisters (whereas one is rich, the other is poor) as well as Justine's paradoxical enjoyment of despair correlate with the film's formal tension. The film unites two different genres: the epic with the lyrical, a sci-fi blockbuster about the end of the world with domestic melodrama. The latter, private, story symbolizes a claustrophobic enclosure of being that has been placed inside an enchanted chalk circle of melancholia and that is desperate to break this spell. The genre is wrenched open and the lyric is united with the epic. On the one hand, everything is being destroyed without becoming a foundation for a new beginning, nothing contradicts the bourgeois order, no true love emerges in place of an inauthentic one. Perhaps this negativity could be explained by the influence of the distant planet? On the other hand, the cosmic plot also disrupts generic stereotypes. No one will save the Earth this time, it will get "happily" destroyed when it collides with Melancholia. Justine, as an epic hero, is incapable of resolving a domestic melodrama - she is simply not built for that. At the same time, Justine's heroism is lacking in scale - it is not sufficient to deal with the challenge of that magnitude. Besides, the proximity of a foreign planet only exacerbates the family's isolation from the external world (they cannot leave their house). This only hints at a synthesis and an expression of this contradiction come through numerous aesthetic quotations. They allow for

the celebration of his patriarch-like father's birthday with his revolutionary and provocative actions. 
the domestic isolated space to be inscribed within a universal scale of human history and to also domesticate this history somewhat. (The protagonist decides to switch a reproduction of a Kandinsky painting with a Breughel).

The film also offers an allegorical depiction of both conflict and interconnection between actor's and spectator's positions, between activity and passivity in art. While art is one of the many things that the planet Melancholia symbolizes, Justine plays the role of a spectator (the scene of her, nude, stargazing is a reference to that). Her depression is partially motivated by the fact that she is forced into the position of a passive viewer. Her immediate fascination with the planet is akin to Hamlet's fascination with the ghost (the film contains a direct reference to Hamlet, when we see Justine floating down the river, looking like Millais' Ophelia). The contradiction here stems from the fact that in von Trier's film, the spectator is called up on stage and the cinematic action is somehow supposed to change this passive position into an active one. As in Shakespeare's Hamlet, an intruder (a planet as an enemy) is ascribed the role the protagonist is secretly dreaming of him or herself. (According to Freud, Hamlet wanted to kill his father and marry his mother himself and it is the fact that all of those actions were performed by his uncle instead of him that disturbed him so much.)

Returning to Malczewski's painting, we can recall that the passivity of his revolutionaries is projected onto the artist's studio and with it onto the constitutive passivity of art itself. The passivity of the fin de siècle's aesthete is, therefore, overcome not through a decisive heroic action, but through a realization of this passivity as a dramatic action. The negativity of experiencing one's passivity becomes a conscious one. Within the play of these contradictions - between the public and the private, art and spectators, love and strife between the two sisters - everything else crashes and burns, leaving the spectator with a sublime feeling of a cosmic force. Artwork itself does not get destroyed, it endures and thrives among a high density of contradictions.

\section{Conclusion}

The parallels between the two Melancholias are obvious. Both works pose a question about being-inside: about the life inside an artwork, within the limits of one's epoch or planet. In both works, the immanence of events is emphasized through the use of reflexive tropes: by a painting within a painting in Malczewski and by playing with paintings and optical devices in Von Trier. Both works combine a dream of transcendence with a jouissance that can be gained only through intense self-absorption. A psychological malaise is experienced in parallel with a grand external 


\section{Illuminated by Darkness: Two Symbolist Masterpieces}

catastrophe. Melancholia is associated not only with a wandering planet or a fear-frozen black witch, but also with trance, into which it hypnotizes its characters and which is painful for an individual who either wants to act but is afraid to (as in the nineteenth century) or is simply too terrified of the world (as in the twenty-first).

And yet, in neither Melancholia do we see a complete breakdown of figurativity, eventfulness, and representation. Neither transitions into the so-called avant-garde. Negativity is pooling inside a painting/film, gathering energy in preparation to either deliver a blow or to protect oneself from it. Artwork stands before the face of history as a subject - and a subject that is more ontologically open than a human subject who hasn't experienced the events yet.

Today, we still belong to the nineteenth century. Neither the optimistic early avant-garde, nor the critical late avant-garde succeeded in overcoming apocalyptic and melancholic tendencies of modernism and modernity (for obvious reasons: after World War Two, the world grew afraid of change and stepped into a route of prolonged restoration). And formalism with its intellectualized games could not compete for a mass audience against the symbolist imagination. It is difficult to assess this phenomenon as a whole. The irrational melancholia of a progressive society should be restrained. Mere reflection of negative content in negative form (as is done in modernism) does not yet stay the urge for selfsuppression. One could try practicing harsh censorship or stamping out formulaic optimistic art, as was done on both sides of the Iron Curtain in the 1950s and 1960s. However, one could also work through the horror by visualizing negativity itself - as an event, a force, and an idea. The object of such symbolist art is manifold: it is the very event of negation, as well as an idealized object that no negation would completely destroy, and is the very threshold between an object and its existence.

Translated by Anastasiya Osipova

\section{References}

Adorno, Theodor (1997). Aesthetic Theory. Trans. Robert Hullot-Kentor. London: Athlone Press.

Aurier, Gabriel-Albert (1891). “Le Symbolisme en Peinture: Paul Gauguin.” Mercure de France, 2.15: 155-65.

Badiou, Alain (2005). Handbook of Inaesthetics. Trans. Alberto Toscano. Stanford: Stanford University Press.

Badiou, Alain (2010). Five Lessons on Wagner. Trans. Susan Spitzer. London: Verso.

Bely, Andrey (1978). Petersburg. Bloomington: Indiana University Press.

Benjamin, Walter (2006a). "The Work of Art in the Age of Its Technological Reproducibility: Third Version.” In Selected Writings, Vol. 4, 1938-1940, ed. Michael W. Jen- 
nings, Howard Eiland, 251-83. Cambridge, MA: Harvard University Press.

Benjamin, Walter (2006b). “Central Park.” In Selected Writings, Vol. 4, 1938-1940, ed. Michael W. Jennings, Howard Eiland, 161-99. Cambridge, MA: Harvard University Press.

Beumers, Birgit (ed.) (2013). Russia's New Fin de Siècle. Contemporary Culture between Past and Present. Chicago: Intellect.

Blok, Alexander (2003). “A Puppet Show.” In Aleksandr Blok's Trilogy of Lyric Dramas, ed. and trans. Timothy C. Westphalen, 19-33. New York: Routledge.

Brown, Clarence and Osip Mandelshtam (1965). "Mandelshtam’s Acmeist Manifesto.” The Russian Review 24.1: 46-51.

Bürger, Peter (1984). Theory of the Avant-Garde. Minneapolis: University of Minnesota Press.

Cavanaugh, Jan (2000). Out Looking In. Early Modern Polish Art, 1890-1918. Berkeley: University of California Press.

Chukovsky, Korney (1904). "Pshibyshevskii o simvole” [Pshibyshevskii on Symbol] Vesi [Libra] 11. http://www.chukfamily.ru/kornei/prosa/kritika/pshibyshevskij-o-simvole.

Clair, Jean (1983). Considérations sur les Beaux-Arts. Critique de la modernité. Paris: Gallimard.

Conio, Gérard (2003). L'art contre les masses: esthétiques et idéologies de la modernité. Lausanne : L’Age d'Homme.

Czekalski, Stanislav (2002). "Hermeneutyka Melancholii, czyli przypowiesc o powstaniu malowanych przeciw obrazowi.” [Hermeneutics of melancholy, or the parable about the creation of painting against the image] In Melancholia Jacka Malczewskiego [Jacek Malczewski’s Melancholia], ed. P. Juszkiewicza, 81-102. Poznan: Wydawnictwo Poznanskiego Towarzystwa Przyjaciol Nauk.

Denis, Maurice (1920). Théories du symbolisme et de Gaugin vers un nouvel order classique. Paris : L. Rouart et J. Watlin.

Denisoff, Dennis (2007). “Decadence and Aestheticism.” In Cambridge Companion to the Fin de Siècle, ed. Gail Marshall, 31-52. Cambridge: Cambridge University Press.

Eco, Umberto (2004). On Literature. Orlando: Harcourt.

Etzioni, Amitai (1970). Demonstration Democracy. New York: Gordon and Breach.

Facos, Michelle, and Thor Mednick (eds.) (2015). The Symbolist Roots of Modern Art. London: Routledge.

Freud, Sigmund (1957). "On the History of the Psycho-Analytic Movement, Papers on Metapsychology and Other Works." In Mourning and Melancholia. The Standard Edition of the Complete Psychological Works of Sigmund Freud, Volume XIV (19141916), 237-58. London: Hogarth Press.

Goethe, Johann Wolfgang (1998). Maxims and Reflections. London: Penguin.

Gibson, Michael (1995). Symbolism. Köln: Taschen.

Heidegger, Martin (2000). Introduction to Metaphysics. Trans. Gregory Fried and Richard Polt. New Haven, CT: Yale University Press.

Heidegger, Martin (2001). Poetry. Language. Thought. Trans. Albert Hofstadter. New York: Harper \& Row. 


\section{Illuminated by Darkness: Two Symbolist Masterpieces}

Heller, Reinhold (1985). "Concerning Symbolism and the Structure of Surface." Art Journal 45.2: 146-53.

Hirsh, Sharon (1985). “Symbolist Art and Literature.” Art Journal 45.2: 95-97.

Hegel, Georg W. F. (1975) Aesthetics. Lectures on Fine Art, Vol 1-2. Trans. T.M. Kox. Oxford: Clarendon Press.

Hegel, Georg W. F. (1983) Hegel and The Human Spirit. A Translation of the Iena Lectures on the Philosophy of Spirit (1805-06) Trans. L. Rauch. Detroit: Wayne State University Press.

Joyce, James (1986). Ulysses. New York: Vintage Books.”

Jullian, Philippe (1971). Dreamers of Decadence. Symbolist Painters of the 1890s. New York: Praeger Publishers.

Lacan, Jacques (1949). “Le Stade du miroir comme formateur de la fonction du Je : telle qu'elle nous est révélée dans l'expérience psychanalytique.” Revue Française de Psychanalyse 13.4: 449-55.

Lifshitz, Mikhail (2009). Pochemu ia ne modernist [Why I am not a modernist]. Moscow: Iskusstvo-XXI vek.

Magun, Artemy (2011). Edinstvo i odinochestvo [Unity and solitude]. Moscow: Novoe Literaturnoe Obozrenie.

Mallarmé, Stéphane (1977). Prose et Vers. Paris: Garnier-Flammarion.

Man'kovskaia, Nadezhda B. (2012) “Esteticheskoe kredo frantsuzskogo simvolizma” [Aesthethic credo of French symbolism]. In Estetika: Vchera. Segodnia. Vsegda [Aesthetics: Yesterday. Today. Always] 5, 20-39. Moscow: IF RAN.

Mathieu, Pierre-Louis (1990). La génération symboliste. Geneva: Skira.

Minsky, Nikolai (1897). Pri svete sovesti: Mysli i mechty o tseli zhizni [In the light of conscience: Thoughts and dreams about the purpose of life]. St Petersburg.: Iu.N. Erlikh.

Moréas, Jean (1886). “Le symbolisme.” Le Figaro, le samedi 18, septembre 1886. Supplément littéraire: $1-2$.

Perlmutter, Dawn (2000). “The Sacrificial Aesthetic: Blood Rituals from Art to Murder.” Anthropoetics 5. 2. http://anthropoetics.ucla.edu/ap0502/blood/

Pelevin, Viktor (1996). Chapaev i pustota [Chapaev and void]. Moscow: Vagrius.

Pelevin, Viktor (2016). S.N.U.F.F. Trans. Andrew Bromfield. London: Gollancz.

Pienkos, Andrzej (2002). "Widma w pracowni na przestrzeni wiekow.” [Spectres of the studio over the centuries] In Melancholia Jacka Malczewskiego [Jacek Malczewski’s Melancholia], ed. P. Juszkiewicza, 45-56. Poznan: Wydawnictwo Poznanskiego Towarzystwa Przyjaciol Nauk.

Rancière, Jacques (2004). The Politics of Aesthetics: The Distribution of the Sensible. London: Continuum.

Rosenblum, Robert (2000). “Art in 1900: Twilight or Dawn?” In 1900: Art at Crossroads, ed. Robert Rosenblum, Mary Anne Stevens, Ann Dumas, 26-53. London: Royal Academy of Arts.

Schelling, Friedrich W.J. (1989) The Philosophy of Art. Trans. D.W. Scott. Minneapolis: University of Minessota Press.

Schulte-Lasse, Jochen (1984). "Foreword: Theory of Modernism vs Theory of Avant- 


\section{Artemy Magun}

Garde.” In Theory of the Avant-Garde, ed. Peter Bürger, vii-xlvii. Minneapolis: University of Minnesota Press.

Thorsen, Niels (2013). Lars von Trier. Melancholia Genia. Trans. Yana Palekhova. Ripol Klassik.

Todorov, Tzvetan (1984). Theories of the Symbol. Ithaca, NY: Cornell University Press. 


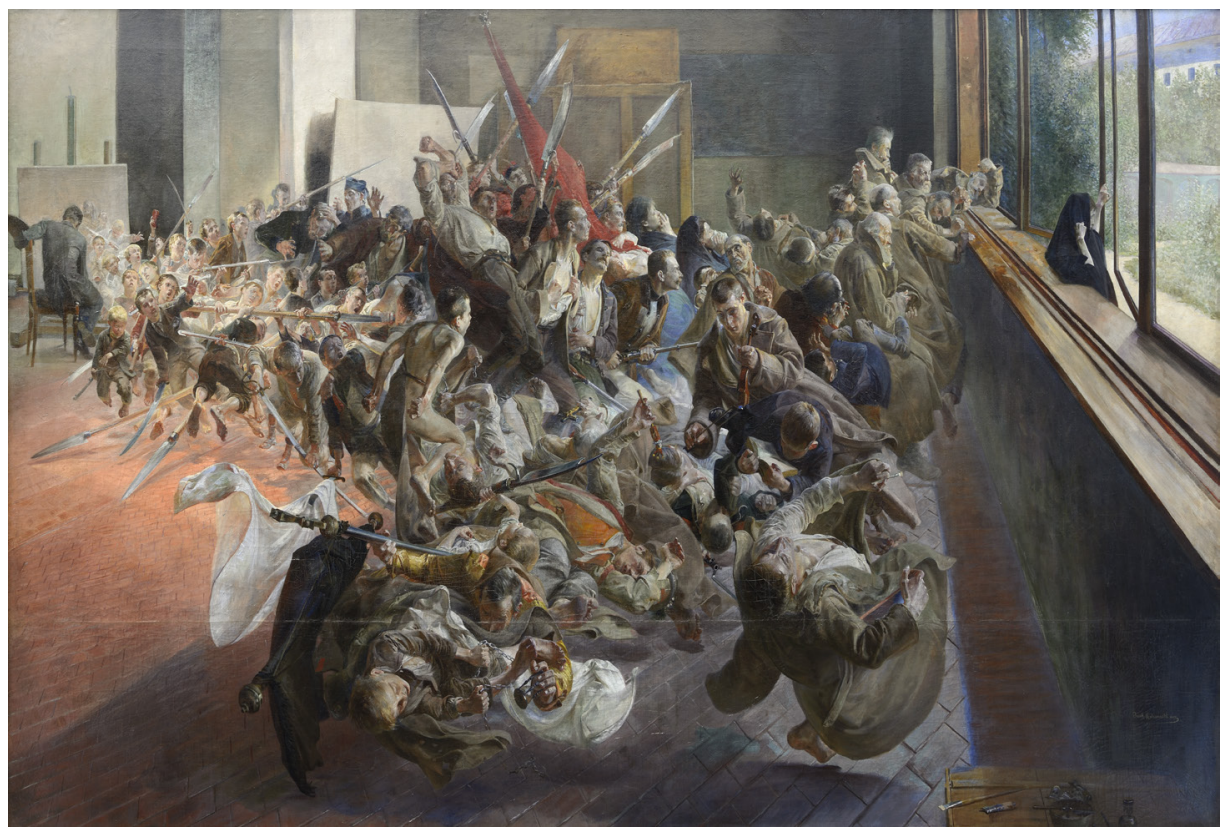

Jacek Malczewski, Melancholia (1890-1894), Muzeum Narodowe w Poznaniu, Poznan 